УДК 35.078

\title{
ДЕРЖАВНЕ РЕГУЛЮВАННЯ СТАЛОГО РОЗВИТКУ ТЕРИТОРІАЛЬНИХ ГРОМАД
}

\section{STATE REGULATION OF SUSTAINABLE DEVELOPMENT OF TERRITORIAL COMMUNITIES}

\author{
Крайник Ольга Петрівна \\ доктор економічних наук, профресор, \\ Львівський регіональний інститут державного управління \\ ORCID: https://orcid.org/0000-0001-6295-3999
}

Kraynyk Olha

Lviv Regional Institute of Public Administration

\begin{abstract}
Розглянуто питання державного регулювання сталого розвитку об'єднаних територіальних громад в умовах завершення реформи децентралізації. Проаналізовано нормативно-правові акти, які повинні забезпечити вирішення комплексу завдань сталого розвитку територій. Розглянуто роль державної регуляторної політики в розв'язанні завдань економічного зростання території, вирішення соціальних завдань та проблем раціонального природокористування. Показана роль фрінансово-бюджетного регулювання сталого розвитку на місцевому рівні. Проаналізовано динаміку виконання місцевих бюджетів за доходами та отримання транссрертів з державного бюджету за останні п'ять років. Показано вплив фінансового регулювання на ефективність виконання власних та делегованих повноважень органами місцевого самоврядування.
\end{abstract}

Ключові слова: державне регулювання, сталий розвиток, територіальні громади, органи місцевого самоврядування, місцеві бюджети, трансферти.

Рассмотрены вопросы государственного регулирования устойчивого развития объединенных территориальных общин в условиях завершения реформы децентрализации. Проанализированы нормативно-правовые акты, которые должны обеспечить решение комплекса задач устойчивого развития территорий. Рассмотрены роль государственной регуляторной политики в решении проблем экономического роста территории, решение социальных задач и проблем рационального природопользования. Показана роль финансово-бюджетного регулирования устойчивого развития на местном уровне. Проанализирована динамика выполнения местных бюджетов по доходам и получение трансорертов из государственного бюджета за последние пять лет. Показано влияние финансового регулирования на эфффективность выполнения собственных и делегированных полномочий органами местного самоуправления.

Ключевые слова: государственное регулирование, устойчивое развитие, территориальные общины, органы местного самоуправления, местные бюджеты, трансорерты.

The article is devoted to the analysis of changes in the state regulatory policy and their impact on the processes of sustainable development of territories. It is shown how decentralization of power provides direct influence of local authorities on sustainable development of the territory. It is emphasized that for the first time in their recent history, territorial communities are responsible for the economic development of their territories, the local social sphere and the preservation of the environment. The task of the state in this context is the formation of an effective regulatory policy capable of ensuring the effectiveness of the tasks. The adoption of the Resolution by the Verkhovna Rada of Ukraine "On the Concept of Sustainable Development of Settlements" in 1999 was the beginning of regulatory influence on sustainable development of territories. In this document, the concept and tasks of sustainable development of settlements are quite clearly outlined. The reasons for which it has been virtually impossible to implement the provisions of this document are defined. The main one has been the permanent lack of necessary financial resources and complete dependence on the center in these matters. The transfer of most powers to the local level and the adoption of a number of regulations gradually begin to address the problems of sustainable development of territories with the beginning of the processes of decentralization only. Changes in the regulatory policy in the field of financial support for the development of territorial communities have been revealed; accordingly, the conditions for solving the most important tasks of state influence on the sustainable development of the territory have been created. Territorial communities receive greater financial resources in the process of fiscal decentralization in the form 
of taxes, fees and other sources of revenue. In addition, the Government of Ukraine annually increases the amount of state financial support for the development of regions and communities by financing state support programs for territorial development. It is shown that the legislation of Ukraine divides the competencies and powers of local governments into their own powers and those delegated by the state. It is considered how the possibilities of their financial provision are divided in this connection. The responsibilities include ensuring balanced economic and social development of the territory, preservation of environment and a number of other tasks related to the management of the territory. The powers delegated by the state are to ensure compliance with social standards of life and responsibility for the functioning of the social sphere. In case of insufficient financial resources to finance delegated powers, the state applies the mechanism of intergovernmental transfers. Thus, in the process of changes and improvements in regulatory policy, conditions are created for solving the most important tasks of state influence on the sustainable development of the territory.

Keywords: state regulation, sustainable development, territorial communities, local self-government bodies, local budgets, transfers.

Постановка проблеми. Побудова громадянського суспільства та формування конкурентоспроможної економіки країни на основі демократичних цінностей, неможлива без ефективного та стабільного розвитку кожної території. Формування активної, виваженої державної регуляторної політики забезпечує можливості розвитку територіальних громад, сприяє посиленню економічних зв'язків окремих територій та підвищенню ефективності взаємодії 3 центральними органами влади. Особливістю сучасного етапу економічного розвитку країни $є$ усвідомлення того, що цей процес прямо залежить від стану розвитку територіальних громад, від уміння і бажання займатись місцевим розвитком своєї території.

Завданням держави у цьому контексті $\epsilon$ формування дієвої регуляторної політики, здатної забезпечити ефрективність реалізації поставлених завдань.

Аналіз останніх досліджень і публікацій. Теоретичні та прикладні засади фрормування регуляторної політики розвитку територіальних громад висвітлені в працях ряду українських вчених-економістів, зокрема М. Хвесик та І. Бистрякова, В. Трегобчук, 3. Лободіна та ряд інших. Однак дослідженню поступовості зміни і удосконалення регуляторної політики та її впливу на сталий розвиток території приділено недостатньо уваги в останніх дослідженнях учених.

Основними цілями статті є аналіз механізму регуляторної політики у ссрері сталого розвитку, висвітлення змін фрінансового забезпечення розвитку територій завдяки активізації процесів децентралізації та прийнятих в зв'язку з цим положень регуляторних актів.

Виклад основного матеріалу. Органи місцевого самоврядування, будучи незалежною інституцією, яка вибирається і підпорядковується лише територіальній громаді, є однією 3 демократичних основ управління суспіль- ством, фрормою реалізації народом влади. Все це підвищує відповідальність місцевої влади за виконання покладених фрункцій, за добробут кожної адміністративно-територіальної одиниці. В цьому контексті найважливішим завданням держави має стати пошук раціонального балансу між децентралізацією управління і управлінням 3 єдиного центру, підтримка спроможності територіальних громад, стимулювання їх розвитку шляхом фрормування ефективної регуляторної політики.

На муніпалізації вирішення завдань сталого розвитку наголошують українські вчені М. Хвесик та І. Бистряков, [1]. які вважають, що «3 синергетичних позицій, відтворення національної господарської системи вимагає вирішення двох проблемних аспектів щодо сталого розвитку територій. Перший стосується ключових моментів, які забезпечують формування парадигми їх максимальної самоорганізації, другий - пов'язаний 3 проблемою муніципалізації територіального простору як одного з головних фракторів, що сприяють самоорганізації співтовариства на базі активізації відтворення локальних господарських систем»

В умовах завершення процесу децентралізації територіальні громади перетворились із об'єкта управління на суб' єкт управління і за цих умов мають можливість самостійно забезпечувати свою спроможність. Місцеві органи управління отримали можливості та мотив для належного виконання як власних, так i делегованих повноважень. Вперше в своїй новітній історії територіальні громади несуть відповідальність за економічний розвиток території, місцеву соціальну сореру та збереження навколишнього середовища. Процес децентралізації передбачає передачу місцевим органам влади більше фрінансових ресурсів та повноважень. При тому більше ресурсів, ширші повноваження вимагають ширшого 
розуміння не тільки загальнодержавних, але і глобальних процесів.

У цьому контексті особливо важливим $є$ приєднання України, як і інших членів ООН, до глобального процесу забезпечення сталого розвитку. В Україні відбулося фрормування Цілей сталого розвитку на 2016-2030 роки а також відповідних завдань і показників для моніторингу досягнення цілей.. В результаті адаптації Цілей сталого розвитку до умов України було підготовлено Національну доповідь «Цілі сталого розвитку: Україна», в якій було визначено національну систему Цілей сталого розвитку [2]. Ця система містить 17 цілей, 86 завдань національного розвитку і 172 показники для їх моніторингу [3].

Ключовим у виконанні цього завдання $€$ орієнтування на досягнення балансу між економічними, соціальними та екологічними цілями. В Україні було розроблено та прийнято ряд законів, спрямованих на реалізацію принципів сталого розвитку. Це, зокрема: Постанова Верховної Ради України від 24 грудня 1999 року № 1359-XIV «Про концепцію сталого розвитку населених пунктів» де було зазначено,що «Сталий розвиток населених пунктів - це соціально, економічно і екологічно збалансований розвиток міських і сільських поселень, спрямований на створення їх економічного потенціалу, повноцінного життєвого середовища для сучасного та наступних поколінь на основі раціонального використання ресурсів (природних, трудових, виробничих, науковотехнічних, інтелектуальних тощо), технологічного переоснащення і реструктуризації підприємств, удосконалення соціальної, виробничої, транспортної, комунікаційно-інорормаційної, інженерної, екологічної інфрраструктури, поліпшення умов проживання, відпочинку та оздоровлення, збереження та збагачення біологічного різноманіття та культурної спадщини [4]. Прекрасно сорормовані завдання цього документа залишились здебільшого не виконаними в попередні періоди.

Продовженням фрормування регуляторної політики в сорері сталого розвитку стало прийняття наступних документів: Указ президента України №722/2019 Про Цілі сталого розвитку України на період до 2030 року [5], Постанова КМУ від 11 листопада 2015 р. № 932 «Про затвердження Порядку розроблення регіональних стратегій розвитку і планів заходів 3 їх реалізації, а також проведення моніторингу та оцінки результативності реалізації зазначених регіональних стратегій і планів заходів» [6]; Наказ Мінрегіону від 30 березня
2016 року № 75 «Про затвердження Методичних рекомендацій щодо фрормування і реалізації прогнозних та програмних документів соціально-економічного розвитку об'єднаної територіальної громади [7]» та ряд інших.

Нові, поставлені в документах цілі, здатні забезпечити вирішення комплексу завдань пов'язаних 3 забезпеченням економічного зростання, вирішення соціальних проблем та проблем раціонального природокористування як кожного адміністративно-територіального утворення, так і країни загалом. Підтвердженням цього $є$ дослідження В. Трегобчук, де зазначається, що «Соціально-економічний розвиток має ґрунтуватися на принципах врахування можливостей природних комплексів витримувати антропотехногенні навантаження і забезпечувати нормальне фрункціонування біоссрери і локальних екосистем. Від цього вирішальною мірою залежать їх корисна продуктивність, якість і комсрортність життєвого середовища, екологічне та економічне благополуччя населення того чи іншого регіону» [8].

Сучасна державна політика України у сорері вирішення завдань сталого розвитку території опирається на інтереси мешканців територіальних громад і передбачає передачу органам місцевого самоврядування значної частини повноважень, ресурсів та відповідальності. При цьому кожен орган місцевого самоврядування в доповнення до загальнодержавної формує свою регуляторну політику, приймаючи місцеві регуляторні акти 3 метою вирішення конкретних завдань території.

Регуляторна політика $є$ основою успіху усіх складових сталого розвитку. Вона повинна бути відкритою, прозорою і загальнодоступною. 32018 року в Україні діє інформаційноаналітична система, що має назву «Регуляторна мапа України» [9]. яка забезпечує автоматизований збір, обробку та розповсюдження інформації про регуляторну діяльність органів державної влади та органів місцевого самоврядування. Це рішення, яке базується на використанні відкритих даних про прийняті нормативно-правові документи на загальнодержавному та місцевому рівні, дозволяє в автоматичному режимі здійснювати моніторинг регуляторної діяльності органів місцевого самоврядування і $з$ мінімальними затратами здійснювати регуляторний нагляд.

Ще одним важливим механізмом стимулювання розвитку територіальних громад $\epsilon$ зміцнення фрінансової бази місцевого самоврядування, забезпечення його реальної самостійності. Фінансова складова економічної само- 
стійності органів місцевого самоврядування $€$ однією з найважливіших в умовах побудови демократичної держави, оскільки визначає реальні можливості виконання фуункцій, покладених на органи місцевої влади. Значна частина фрінансових ресурсів зосереджується в місцевих бюджетах, кошти яких використовуються на задоволення потреб населення територіальних громад, покращення якості надання державних послуг. Реалізація зазначених завдань органами місцевої влади відбувається через їх участь у формуванні та реалізації бюджетної політики, а здатність місцевої влади виконувати свої фуункції базується на реальній участі в бюджетному процесі та розподілі грошових коштів. Стаття 142 Конституції України [10] встановлює, що матеріальною та фрінансовою основою місцевого самоврядування $€$ рухоме і нерухоме майно, доходи місцевих бюджетів, інші кошти, природні ресурси, які є власністю територіальних громад. Територіальна громада має право на срормування власного бюджету, створення позабюджетних фрондів грошових коштів. Бюджетно-фрінансова децентралізація є результатом розподілу повноважень та їх узгодження між виконавчою та представницькою владою. Рівень бюджетно-фрінансової децентралізації $\epsilon$ показником рівня бюджетної і податкової автономії місцевих органів щодо управління розвитком територій.

Активізація процесів децентралізації і як результат прийняття змін до Бюджетного кодексу [11], та Податкового кодексу [12] забезпечують збільшення надходжень до місцевих бюджетів та посилення ролі органів місцевого управління у соціально економічному розвитку території. Динаміка власних надходжень до загального фонду місцевих бюджетів показана у табл. 1 [13].

Таблиця 1

Доходи загального фонду місцевих бюджетів (без урахування міжбюджетних трансфертів) за період 2016-2020 рр., млрд. грн.

\begin{tabular}{|c|c|c|}
\hline Роки & Сума доходу & $\begin{array}{c}\text { Приріст до } \\
\text { попереднього } \\
\text { періоду, \% }\end{array}$ \\
\hline 2016 & 146,6 & 49,3 \\
\hline 2017 & 191,9 & 30,9 \\
\hline 2018 & 233,9 & 21,9 \\
\hline 2019 & 275,0 & 17,6 \\
\hline 2020 & 290,0 & 5,4 \\
\hline
\end{tabular}

Закон України «Про місцеве самоврядування» [14] визначає компетенції та повно- важення органів місцевого самоврядування, основним 3 яких $€$ виконання власних та делегованих державою повноважень. Зокрема, до власних повноважень віднесено забезпечення збалансованого економічного і соціального розвитку території, управління об'єктами житлово-комунального господарства, побутового і торговельного обслуговування, транспорту і зв'язку тощо. Делеговані державою повноваження полягають у забезпеченні виконання суспільних стандартів життєдіяльності та життєзабезпечення населення з урахуванням економічних умов і стратегії розвитку країни.

3. Лободіна наголошує на необхідності впливу держави на здатність органів місцевого самоврядування виконувати делеговані повноваження, вважає, що «...в умовах децентралізації управління поряд із передачею значних фрункцій держави на місцевий рівень спостерігається недостатність обсягу власних та закріплених доходів місцевих бюджетів для фрінансування виконання повноважень органів місцевого самоврядування. А тому при розробці та реалізації бюджетної політики держави виникає необхідність використання такого важелю бюджетного механізму як міжбюджетні трансферти» [15].

Рівень виконання делегованих повноважень залежить від можливостей державного бюджету. Водночас недостатнє наповнення місцевих бюджетів у ряді територіальних громад пов'язане з низьким рівнем фрінансування соціальних видатків, оскільки на місцеві органи влади лягає основна відповідальність за фрункціонування соціальної ссрери. В цьому випадку держава застосовує механізм міжбюджетних трансфрертів, який забезпечує реалізацію основних цілей політики міжбюджетного регулювання, які полягають по-перше у вирівнюванні бюджетної забезпеченості різних адміністративно - територіальних одиниць країни, у створенні стимулів для заохочення місцевих бюджетів, що забезпечують успішну мобілізацію доходів у консолідований бюджет території, по-друге.

В цілому використання системи міжбюджетних транссрертів повинно:

- сприяти ліквідації горизонтального дисбалансу у фрінансовому забезпеченні адміністративно-територіальних одиниць в межах всієї країни;

- створювати фрінансові можливості виконання делегованих повноважень органів державної влади на рівні окремої території;

- забезпечити функкціонування соціальної ссрери незалежно від податкоспроможності адміністративно-територіальної одиниці. 
Динаміка надходження коштів 3 Державного бюджету місцевим бюджетам у вигляді міжбюджетних транссрертів за 2016-2020 рр. представлена в табл. 2 [16].

Перерахування міжбюджетних Таблиця 2 трансрертів місцевим бюджетам

\begin{tabular}{|c|c|c|}
\hline Роки & $\begin{array}{c}\text { Сума } \\
\text { міжбюджетних } \\
\text { трансфертів, } \\
\text { млрд. грн. }\end{array}$ & $\begin{array}{c}\text { Частка } \\
\text { від передбачених } \\
\text { розписом } \\
\text { асигнувань, \% }\end{array}$ \\
\hline 2016 & 196,0 & 99,6 \\
\hline 2017 & 272,9 & 97,8 \\
\hline 2018 & 285,5 & 99,1 \\
\hline 2019 & 245,4 & 95,8 \\
\hline 2020 & 161,0 & 98,0 \\
\hline
\end{tabular}

У процесі бюджетного регулювання створюються умови для розв'язання найбільш важливих завдань державного впливу на сталий розвиток території. Необхідність забезпечення узгодженого фрункціонування всіх елементів бюджетної системи і важливість своєчасного вирішення наявних суспільних проблем призводять до того, що бюджетний процес виступає в якості об'єкта державного регулювання.

Окрім коштів, отриманих органами місцевого самоврядування в процесі фріскальної децентралізації у вигляді податків, зборів та інших джерел надходжень, Уряд України щороку збільшує обсяг державної фрінансової підтримки розвитку регіонів та громад шляхом фрінансування програм державної підтримки розвитку територій. Так, у 2018 році обсяг такої підтримки склав понад 66 млрд. грн, у 2019 - понад 84 млрд. грн., в тому числі за рахунок державного сронду регіонального розвитку (ДФРР) - 7,67 млрд. грн. Кошти державної підтримки розвитку територій спрямовуються за різними напрямами: регіональний розвиток; розвиток дорожньої та транспортної інфрраструктури; розвиток сільських територій; енергоесрективність; екологічна безпека та сталий розвиток, розвиток у сфрері освіти, культури, охорони здоров'я тощо [17]. На підтримку місцевих проектів з ДФРР у Державному бюджеті на 2021 рік передбачено 4,5 млрд. гривень на Державний фронд регіонального розвитку [18].

Висновки. Таким чином однією $з$ найважливіших умов забезпечення сталого розвитку території $€$ фрормування сприятливої регуляторної політики як на загальнодержавному, так і на місцевому рівні. Ефективна регуляторна політика передбачає синтез адміні- стративного та економічного регулювання, недопущення прийняття економічно недоцільних та неефективних регуляторних актів, стимулювання діяльності суб'єктів господарювання, детінізації бізнесу з метою забезпечення сталого розвитку територіальних громад. 3 метою забезпечення прозорості прийняття положень нормативно-правового регулювання слід активізувати роботу в межах проекту «Регуляторна мапа України». Такий підхід дозволить визначати рівень зарегульованості бізнесу у тій чи іншій територіальній громаді, виявити стан виконання органами місцевого самоврядування положень регуляторного законодавства, здійснювати регуляторний нагляд в автоматичному режимі, та виявляти неефективні рішення, що сприятиме усуненню бар'єрів економічного розвитку територій і обмін досвідом щодо удосконалення місцевої регуляторної політики. Особливе значення у забезпеченні сталого розвитку територіальних громад займає бюджетно-фрінансове регулювання, яке повинно базуватись на ефективній політиці забезпечення доходами територіальні утворення в поєднанні з фрінансовою підтримкою з централізованих джерел орінансування.

В умовах децентралізації управління основну роль у наповненні місцевих бюджетів повинна відігравати ініціатива органів місцевого самоврядування. Своєю чергою держава регуляторними актами може сприяти зацікавленості місцевої влади у збільшенні надходжень фрінансових ресурсів територіальних громад. У той же час для виконання делегованих повноважень держава виділяє кошти місцевим органам влади в вигляді міжбюджетних транссрертів. Це означає використання комплексного підходу, який включає поєднання ресурсів, які надходять як з власних джерел, так і з надходжень від централізованих фрондів фрінансових ресурсів. Збільшення фрінансових можливостей територіальних громад, підвищення есрективності їх використання забезпечить досягнення поставлених цілей і індикаторів сталого розвитку в інтересах населення адміністративно-територіального утворення. Використання такого бюджетного механізму як міжбюджетні транссрерти дозволить покращити фрінансування виконання делегованих повноважень органів місцевого самоврядування. Загалом за умови фрормування ефрективної системи регулювання всіх складових процесу сталого розвитку досяжною стає ціль підвищення рівня і якості життя населення всіх територій. 


\section{СПИСОК ВИКОРИСТАНИХ ДЖЕРЕЛ:}

1. Хвесик М., Бистряков І. Парадигмальний погляд на концепт сталого розвитку України. Проблеми економічної теорії. URL: file://C:/Users/One/Downloads/EkUk_2012_6_2\%20(1).pdf

2. «Цілі сталого розвитку: Україна». URL: https://www.kmu.gov.ua/diyalnist/cili-stalogo-rozvitku-ta-ukrayina

3. Моніторинг показників досягнення ЦСР в Україні. URL: https://niss.gov.ua/sites/default/files/2019-10/ prezentaciya-csr_22.10.2019_karmazina.pdf

4. «Концепція сталого розвитку населених пунктів». URL: https://zakon.rada.gov.ua/laws/show/1359-14\#Text

5. Указ Президента України «Про Цілі сталого розвитку України на період до 2030 року». URL: https://zakon.rada.gov.ua/laws/show/722/2019\#Text

6. Про затвердження Порядку розроблення регіональних стратегій розвитку і планів заходів з їх реалізації, а також проведення моніторингу та оцінки результативності реалізації зазначених регіональних стратегій і планів заходів. URL: https://zakon.rada.gov.ua/laws/show/932-2015-\%D0\%BF\#Text

7. Про затвердження Методичних рекомендацій щодо фрормування і реалізації прогнозних та програмних документів соціально-економічного розвитку об'єднаної територіальноїгромади. URL: https://zakon.rada.gov.ua/ rada/show/v0075858-16\#Text

8. Трегобчук В. Концепція сталого розвитку для України. Вісник НАН України. 2002. № 2.

9. Регуляторна мапа України. URL: https://opendata.in.ua/map

10. Конституція України. URL: https://zakon.rada.gov.ua/laws/show/254\%D0\%BA/96-\%D0\%B2\%D1\%80\#Text

11. Бюджетний кодекс України. URL: https://zakon.rada.gov.ua/laws/show/2456-17\#Text

12. Податковий кодекс України. URL: https://zakon.rada.gov.ua/laws/show/2755-17

13. Виконання доходів місцевих бюджетів. URL: https://mof.gov.ua/uk/vykonannia-dokhodiv-mistsevykh-biudzhetiv

14. Закон України «Про місцеве самоврядування в Україні». URL: https://zakon.rada.gov.ua/laws/show/280/97\%D0\%B2\%D1\%80\#Text

15. Лободіна 3. Міжбюджетні трансферти: реалії надання та шляхи удосконалення в контексті зміцнення фінансової бази органів самоврядування. URL: http://library.wunu.edu.ua/images/stories/praci_vukladachiv/

16. Виконання доходів місцевих бюджетів. URL: https://mof.gov.ua/uk/vykonannia-dokhodiv-mistsevykh-biudzhetiv

17. Розпорядження Кабінету Міністрів України «Про розподіл у 2020 році субвенції з державного бюджету місцевим бюджетам на здійснення заходів щодо соціально-економічного розвитку окремих територій». URL: https://www.kmu.gov.ua/npas/891-080720

18.294 проекти регіонального розвитку відібрані для фрінансування у 2021 році коштом ДФРР. URL: https://www.kmu.gov.ua/news/294-proekti-regionalnogo-rozvitku-vidibrani-dlya-finansuvannya-u-2021-rocikoshtom-dfrr

\section{REFERENCES:}

1. Khvesyk M.,Bystriakov I., Paradyhmalnyi pohliad na kontsept staloho rozvytku Ukrainy. Problemy ekonomichnoi teorii. URL: file://C:/Users/One/Downloads/EkUk_2012_6_2\%20(1).pdf

2. "Tsili staloho rozvytku: Ukraina". URL: https://www.kmu.gov.ua/diyalnist/cili-stalogo-rozvitku-ta-ukrayina

3. Monitorynh pokaznykiv dosiahnennia TsSR v Ukraini. URL: https://niss.gov.ua/sites/default/files/2019-10/ prezentaciya-csr_22.10.2019_karmazina.pdf

4. «Kontseptsiia staloho rozvytku naselenykh punktiv». URL: https://zakon.rada.gov.ua/laws/show/1359-14\#Text

5. Ukaz Prezydenta Ukrainy «Pro Tsili staloho rozvytku Ukrainy na period do 2030 roku». URL: https://zakon.rada.gov.ua/laws/show/722/2019\#Text Pro Tsili staloho rozvytku Ukrainy na period do 2030 roku

6. Pro zatverdzhennia Poriadku rozroblennia rehionalnykh stratehii rozvytku i planiv zakhodiv z yikh realizatsii, a takozh provedennia monitorynhu ta otsinky rezultatyvnosti realizatsii zaznachenykh rehionalnykh stratehii i planiv zakhodiv. URL: https://zakon.rada.gov.ua/laws/show/932-2015-\%D0\%BF\#Text

7. Pro zatverdzhennia Metodychnykh rekomendatsii shchodo formuvannia i realizatsii prohnoznykh ta prohramnykh dokumentiv sotsialno-ekonomichnoho rozvytku obiednanoi terytorialnoi hromady. URL: https://zakon.rada.gov.ua/rada/show/v0075858-16\#Text

8. V. Trehobchuk (2002). Kontseptsiia staloho rozvytku dlia Ukrainy. Visnyk NAN Ukrainy, no. 2.

9. Rehuliatorna mapa Ukrainy. URL: https://opendata.in.ua/map

10. Konstytutsiia Ukrainy. URL: https://zakon.rada.gov.ua/laws/show/254\%D0\%BA/96-\%D0\%B2\%D1\%80\#Text

11. Biudzhetnyi kodeks Ukrainy. URL: https://zakon.rada.gov.ua/laws/show/2456-17\#Text

12. Podatkovyi kodeks Ukrainy. URL: https://zakon.rada.gov.ua/laws/show/2755-17

13. Vykonannia dokhodiv mistsevykh biudzhetiv. URL: https://mof.gov.ua/uk/vykonannia-dokhodiv-mistsevykhbiudzhetiv 
14.Zakon Ukrainy «Pro mistseve samovriaduvannia v Ukraini». URL: https://zakon.rada.gov.ua/laws/ show/280/97-\%D0\%B2\%D1\%80\#Text

15. Lobodina Z. Mizhbiudzhetni transferty: realii nadannia ta shliakhy udoskonalennia v konteksti zmitsnennia finansovoi bazy orhaniv samovriaduvannia. URL: http://library.wunu.edu.ua/images/stories/praci_vukladachiv/

16. Vykonannia dokhodiv mistsevykh biudzhetiv. URL: https://mof.gov.ua/uk/vykonannia-dokhodiv-mistsevykhbiudzhetiv

17. Rozporiadzhennia Kabinetu Ministriv Ukrainy «Pro rozpodil u 2020 rotsi subventsii z derzhavnoho biudzhetu mistsevym biudzhetam na zdiisnennia zakhodiv shchodo sotsialno-ekonomichnoho rozvytku okremykh terytorii». URL: https://www.kmu.gov.ua/npas/891-080720

18.294 proekty rehionalnoho rozvytku vidibrani dlia finansuvannia u 2021 rotsi koshtom DFRR. URL: https://www.kmu.gov.ua/news/294-proekti-regionalnogo-rozvitku-vidibrani-dlya-finansuvannya-u-2021-rocikoshtom-dfrr 